\title{
CHINESE PERCEPTION OF INDO-US NEXUS: IMPLICATIONS FOR CHINA IN SOUTH ASIAN REGION (Brief Overview)
}

\author{
R.D. Nisar \\ Central China Normal University \\ 152, Luoyu Road, Wuhan, Hubei, People's Republic of China, 430079
}

\begin{abstract}
After the collapse of the USSR, the US changed its policies, shifted its priorities and started viewing China's economic emergence as a great threat to US interests. Due to the rapid economic growth and military development, the People's Republic of China has become a rival for the US in the global arena. Meanwhile, as the US is reshaping its policy in accordance with the modern geopolitical reality, it starts regarding India as a powerful ally for holding China back. The close rapport between India and the USA is being established on the account of economic liaisons and combined efforts against security threats. Currently, India and the US are redefining their affiliations and building a potent nexus to secure their common interests, particularly in keeping China at bay. The formation of amicable Indo-US relations has resulted in the collective agenda for achieving the two countries' common objectives in Asia. According to A. Tellis, the two foremost strategic goals of the two countries in Asia are: firstly, to contain the growing influence of China in Asia and its adjacent territories and establish Indian hegemony in the region; secondly, to promote friendly relations with other major actors in the region in order to garner support for India. The two countries' strategic plan towards China is to isolate the country from the rest of the region. The presence of the US naval forces in the Indian Ocean and recent military exercises in Malabar have increased the US-India ties and have helped to establish control over Chinese naval and trade routes and sea lines of communication. Senior US officials have openly declared their intentions of strategic containment of China. As was noted by one of India's leading political analysts John Cheian, "Washington's primary goal is developing alliance with India in order to contain China". The given article presents an outlook on the Chinese perception of the US-India nexus.
\end{abstract}

Key words: India-US Nexus, Containment, Indian Ocean, Sea Lines of Communication, China and South Asia, Sino-Russian relations

\section{INDIA-US NEXUS AND CHINESE PERCEPTION}

After the collapse of the USSR, the strategic positions in the Asian political arena have changed. China's emergence as a major world power has become a key milestone in contemporary Asian politics. From the perspective of power distribution in the region following Beijing's rise, as some analysts have realistically pointed out, all regional politics will be shaped around China. Therefore, the US primary interests in Asia are to promote peace and stability as well as create a balance of power in the region and

(C) Nisar R.D., 2019.

(C) (1) This work is licensed under a Creative Commons Attribution 4.0 International License https://creativecommons.org/licenses/by/4.0/ 
prevent hegemony by any power or group of powers. As the former US secretary of state James Baker pointed out, "Since $19^{\text {th }}$ century, the basic principle of the US national security was to prevent Asia from being dominated by any power or group of powers which challenged the US hegemonic position in Asia". Japan was defeated by the US in 1945, and today's US strategy is to curb Chinese development, which is similar to the $19^{\text {th }}$ century strategy of Great Britain, when it tried to stop the spread of influence of the peripheral states. According to Huntington, "it is possible for the US to counter China, if other Asian states would like to counter China as well". So far, India has been trying to achieve its major strategic interests in two main directions: first, secure its economic and, in particular, energy interests in the region and second, expand its power beyond the territory of South Asia [6]. In the way of these ambitions, however, there exists one obstacle: according to Indian political pundits, India regards China as its principal current challenge in the region. The strong Indo-American relations will give New Delhi an opportunity to balance out Chinese dominance in the region. On this subject, foreign secretary Shyam Saran commented: "I think India and the US can contribute to a much better balance in the region, considering it was China's rise that was upsetting the balance in the first place" [5]. According to Indian high officials, since US advanced technology and military equipment arrived in India, the country is becoming an important centre of power leading to the redistribution of balance on the Asian arena. At the same time, the US leaders stated that China is the central element in their efforts to encourage India's emergence as a world power [3]. The Indo-US nexus was officially created on July 5, 2005, when the leaders of the two of the nations signed the Civil Nuclear Agreement and discussed former US policies towards India, in particular, those of the Clinton administration. Meanwhile, Beijing perceives this nexus as an attempt by both democracies to enlist New Delhi as a potential counterweight adjacent to China. Ever since the Bush administration entered office, the US has seen India as a major political player and an emerging powerful economy, acknowledging its vital role in Asian stability and its potential to balance out Chinese influence in the Asian region [10].

Chinese academics firmly believe that the ongoing dynamic of India-US engagement in Asia is a part of the US anti-sinitic policy with a view to isolate "the mighty China" in the future. The Indo-US strategic collaboration, which includes joint military and naval exercises, defense conferences, as well as shipments of American weapons and defense technology to India, are aimed to curb China's growing power in Asia. The US military equipment, such as the maritime reconnaissance aircraft PC Orion and Aegis radar system, are targeted specifically to track Chinese maritime activities in the sea lines of communications (SLOC) [8].

In the meantime, Beijing recognizes that Washington's support of New Delhi is part of the US global strategic plan to play off India against rising China. As was summed up by China's official media in regards to the US military support of India, "US dreams of Asian NATO". At the 2008 Bucharest NATO summit, US president Bush declared: "Now NATO would send its forces across the world for the future of freedom and peace of millions". Thus, a new alliance was formed, drawing the dream of "Asian NATO" closer and making Russia and China the main obstacles in its way. According 
to the US policy makers, India has a crucial strategic position connecting two important oceans (Indian and Pacific), and by means of reinforcing the Indo-American partnership, the US will expand its presence in South Asia and weaken Russian and Chinese strategic capabilities in the region [11]. According to the Chinese leadership, the US main intention is to build closer ties with India, create an Asian version of NATO and, thus, expand its hegemony and secure its interests in Asia [11]. In the context of the robust Indo-US relations, the US has been consistently establishing its hegemony striving towards full control of the Asian region in general and South Asia in particular. As was stated by Liu Jianfei, "The core content of the US global strategy since the 20th century has been to establish and consolidate its world leadership status, or in other words, to contend for and maintain its world hegemony status and contain its enemy (China)" [11]. Ever since the end of the Cold War, China has remained the only country with rapid economic growth. Its defensive capabilities have challenged the US global leadership, so Washington, who sees China as the main competitor, has adopted containment strategies to curtail Chinese presence in the Asian region and especially in sea lines of communication (SLOC), which involve, above all else, tracking Chinese movements in the maritime checkpoints [9]. In terms of distribution of power, Chinese officials believe that the Indo-US nexus will bring a major shift in the power balance in South Asia and the Indian Ocean Region, because, as was justly noted by A. Mahan, a prominent naval analyst, "whoever controls the Indian Ocean dominates Asia" [2].

The Indian Ocean has seven seas, so it provides all of the major sea routes, making the Indian Ocean Region (IOR) the most strategically important territory in the contemporary world. The IOR provides the predominant outlet for oil to various destinations, which is where China's most vital interests lie, as Beijing tries to secure its energy ambitions. India remains the most predominant power in the IOR due to its direct access to the Indian Ocean, which makes it China's principal competitor. The India-US joint naval and military exercises in the maritime lines sent a powerful message to China. In an attempt to overcome its geographic weakness and strengthen its national security, as well as gain full access to the Indian Ocean, China started expanding its naval positions in the IOR through applying a number of strategies, such as 'strings of pearl', 'periphery strategy' and OBOR (One Belt One Road) initiative. According to Chinese analyst Zhao, "Whoever controls the Indian Ocean and its periphery, especially the Malacca Strait, could endanger China's oil supply route" [8]. Furthermore, it was implicitly mentioned that numerous powers (including the US) have been trying to increase their presence in the Malacca Strait while attempting to control and monitor Chinese naval navigation there. Prominent Chinese strategists believe that in the case with the Indian Ocean, America will strive to contain Beijing's ambitious plans. An editorial in Ming Pao explained that "according to the American policy makers, to control the Indian Ocean means to control Asia". Summarizing the above, through its alliance India and Japan (the India-US-Japan nexus), the US has been able to establish and maintain a visible and credible presence in the Indian Ocean Region [4].

The sea lines of communication in the Indian Ocean and the Malacca Strait are the oil lifeline for China, Korea and Japan, because via the IOR SLOCs oil is shipped 
from the Persian Gulf to various destinations all over the world. If America and its allies control the Indian Ocean SLOCs, the three oil importing countries can become perfectly isolated, which will affect China the most. Therefore, the major objective of China's Asian strategy is to stop the formation of such alliances as Indo-US or Indo-US-Japan coalitions, as well as the quadrilateral alliance US-Japan-Australia-India, against China and prevent anti-Chinese policies put forward by the US and its allies [13].

On January 29, 2002, US president Bush placed China at the top of the list of its rivals across the Taiwan Strait and in Asia. The subsequent president of the United States Barack Obama was more friendly and cooperative towards China, as was observed by political analysts. But this observation was later disputed by Evan Feigenbaum, a member of the Bush administration, in his article in Foreign Affairs: "Many in India believe that the Obama administration has tilted its policy towards Beijing in a way that undermines Indian interests but Obama's China policy is broadly consistent with that of every US president since Richard Nixon." Eventually, it has become evident that as a result of the formation of the Indo-US nexus, both countries were able to secure their interests and succeeded in their attempts to counter their common rival China [11].

\section{REGIONAL IMPLICATIONS FOR CHINA}

India has become an important global actor after forming an alliance with a world superpower, the United States, and now plays a vital role in the world's politics. Robert Blackwill, the US ambassador to India, suggested that "the US and India should get together to face the challenges from the enemy beyond the third mountain range". The US leadership's commitment to contain China is obvious. It is also apparent that the Indo-US nexus impacts China's strategic, political, and economic interests in three regions crucial from the point of view of China's peripheral security: South Asia, Central Asia and East Asia. Below, we elaborate on the implications of the Indo-Pacific alliance for China and offer a description of strategies adopted by China in the South Asian region.

\section{CHINESE POLICES REGARDING THE SUB-CONTINENT REGION}

South Asia has recently become a hub for intense global activity: several global, regional and sub-regional actors are competing to establish their influence on its territory. Apart from the key regional players - India, China and Japan, — a few overseas competitors have demonstrated their active involvement, the USA being the most influential of them. Another factor contributing to the distribution of power in South Asia is the existence of nuclear states, among which the US and China are preeminent players with the capacity to change the political dynamics and stability of the region. At the same time, both view each other as contestants, while many American analysts see the partnership with India as a way to create counterbalance to China. With the Cold War rhetoric of 'estranged democracies' no longer being pertinent, these two countries have become 'engaged democracies' [9].

The alliance with the US has boosted Indian importance in the region. Indian political and economic development models are shaped according to the western stand- 
ards; meanwhile, China is pursuing a different course. China's growing military and economic power poses a threat to the US influence in the region, which is why Washington is attempting to fence China off by means of making allies like India [5]. At the same time, Beijing, aware of Washington's attempt to counter China politically, strategically and economically through building a range of partnerships with India in the spheres of economy, defense and security, is doing whatever it takes to decrease the influence of the Indo-Pacific alliance and counter its anti-Chinese policies [6].

Among China's primary interests in sub-continent region and its adjacent ocean is gaining access to markets and natural resources. At the same time, Beijing needs to stay alert and apply all necessary measures to counter any anti-China policies. In the $21^{\text {st }}$ century, Chinese foreign policy in the sub-continent region has been based on bilateral diplomatic relations with South Asian states in the context of mutual trust, equality, economic collaboration and peaceful co-existence. China is trying to build neighbourly relations with India, while maintaining strategic cooperation with Pakistan and developing a maritime security strategy in the Malacca Strait and the Indian Ocean in order to decrease the influence of the Indo-American nexus [10].

China's South Asian policy is guided by its "periphery strategy", which is based on establishing friendly relations with its immediate neighbours. Among China's aspirations regarding the development of the situation in the South Asian region are:

- peaceful coexistence;

- regional security;

- respect and international recognition;

- peace and stability;

- economic development;

- anti-hegemonism;

- multi-lateral political system;

- harmonious world order;

- regionalism.

China's "periphery strategy" is aimed, in the first place, at maintaining stable mutually beneficial relations with neighbouring areas. One Belt One Road (OBOR) initiative combines the "periphery strategy" and "string of pearls" concept. Through realizing OBOR, Chinese government is constructing infrastructure in various regions, such as Africa, South Asia, Central Asia and Europe. The main objective is to counter and decrease the influence of the Indo-US collaboration in the IOR and Asia. China has rapidly extended its naval activity in the Indian Ocean littoral zone and is building railroads to obtain an alternative route through South and Southeast Asia to deliver oil and gas from the Persian Gulf [12].

The Chinese "string of pearls" strategy also serves to hinder the activity of the IndoUS coalition in the Asian region. S.E. Smith, a renowned political analyst, defines the "string of pearls" as "a strategic move which involves establishing a series of nodes of military and economic power throughout a region. Each node is a "pearl" in the string, enhancing the overall power of the parent nation". The key objective of China's "string of pearl" strategy is to secure the energy supply through foreign oil and trade routes. Beijing increased its geopolitical influence in the region through concerted efforts 
to increase access to major ports, expand and modernize military forces, and foster stronger diplomatic relationships with trading partners by means of investments. China's network of military and commercial facilities extends from the South China Sea and Hainan Island all the way to the Malacca Strait [13]. Beijing increases its naval presence in main strategic maritime centers in Bangladesh, Myanmar, Sri Lanka, the Maldives, Thailand, Cambodia and the Gwadar port in Pakistan. It also expands its influence across the Indian Ocean, Arabian Sea and Persian Gulf, which sums up the essence of OBOR initiative [11]. The clash of global interests in the Asian region and the adjacent Indian Ocean, Pacific Ocean and Persian Gulf indicate the strategic significance of the sea lines of communication in the area. Over the last two decades, the Chinese government has been steadily developing its maritime activity in the Indo-Pacific region: the PLA-Navy is increasing its presence in the Indian Ocean by means building ports, harbours, maritime communication stations and other facilities along its major SLOCs with the key goal to curb the Indo-US influence in the IOR [10]. The Indian Ocean is crucial for both India and China in the context of their security, economic and energy interests. India is striving towards establishing hegemony in the Indian Ocean and is willing to side with other sub-regional and global nations to secure common interests and tame China's ambitions, which resulted in the creation of the Indo-Pacific alliance. The leaders of the both nations, who share the same democratic values, seek full-fledged collaboration in the fields of security, economics and diplomacy [10].

India is particularly concerned with security in the IOR. It is increasing its military presence and training its navy to deal with security issues in the region, such as illegal trafficking, proliferation of WMD and terrorism. Indo-US joint naval exercises allow the allied forces to monitor the Indian Ocean SLOCs starting from the Gulf all the way to East Asia. China, whose interests lie in the IOR as well, is upgrading its military training and increasing the number of naval communication links with Asian countries with the purpose of obtaining naval supremacy in the Indian Ocean [1]. The two rival states, China and India, are struggling for advantage in the Indian Ocean periphery. The chief goals of Indian naval expansion in the IOR are to keep the Chinese army (PLN) out of the Indian Ocean, enter the South China Sea and emplace its military power directly by the Chinese homeland, as well as to monitor the Indian Ocean's choke points, for instance, the Malacca Strait [5]. Sponsored by the USA in the context of the Indo-US alliance, the Indian navy received new advanced military technology, such as IAF lethal weapons, Phalcon AWAS aircrafts, TU-142m, and IL-38 submarines. While regional security remains one of the Indian government's chief concerns, the main purpose of this armed forces upgrade is to match China's military potential [10]. According to a Chinese navy official, the expansion of the "Blue water navy" in the Indian Ocean is a serious threat to Chinese objectives in the region, because India still did not get over its defeat in the 1962 conflict [6].

The new military technology, obtained by the Indian army (LSTs, INS Mysore, INS Mumbai, MIG-29K, Harvier MK51, King MK.42, Helicopters KA-31AEW), as well as the Malabar training exercises under US guidance, are part of India's naval expansion strategy [6]. Although both US and Indian leaders officially declared that these military exercises are nothing more than a regular training of naval forces, the 
basic purpose of which is to improve cooperation, share communications, test air defense, and cross-check helicopters in water, China remained unconvinced [8]. According to the Chinese government, the Indo-US cooperation in the Indian Ocean and maritime sea lines, including the Malabar exercises and supply of the new military technology to India, are part of the alliance's military strategy and its ill-disguised attempt to encircle China in Asia and diminish its influence. An editorial in the People's Daily noted that "the quadrilateral alliance among Japan, India, Australia and the US is focused on China with a purpose of encircling it in every context" [10]. The shipment of Indian arms to Myanmar, the construction of the Indo-Myanmar gas pipeline and conduction of the Indo-Myanmar naval exercises all testify to an active cooperation between New Delhi and Naypyidaw, aimed at expanding Indian supremacy in the Indian Ocean. Since 2005, the Malabar exercises have been a major joint event organized by the two countries, followed by the 2011 and the 2013 exercises near Okinawa in Japan. Chinese officials view the Indo-US naval cooperation as part of Indian 'look east' policy [4]. Suresh Metha, a chief Indian navy officer, declared: "We are ready to close up the Chinese power in the Indian Ocean with expansive and modern military weapons as well as with new ambitions". To counter the Chinese policy of "strings of pearl", Indian policy-makers offered the term "encirclement" to refer to India's strategy of curbing Chinese influence. Another officer, by the last name of Paraksh, mentioned that the principal objective of the "strings of pearls" strategy is to counter India's rise and create hurdles in the way of the powerful Indo-US nexus [10]. The two democracies' collaboration, from 2009 to present, has been aimed at gaining supremacy in the Indo-Pacific region. This collaboration has been reinforced by different measures, such as the US arms sales to Taiwan, military exercises in the Yellow Sea in September 2010, exercises in the South China Sea in 2011, and exercises in Vietnam and Philippines in 2010 and 2011 respectively. According to China, these attempts are all directed at isolating China politically, economically and strategically [11].

Apart from the US, India has been instituting maritime communication links with other countries, with a view to establish exclusive dominance in the Indian Ocean [3]. Joint naval drills with overseas partners included TROPES in the east and west fleets, JIMEX-12 with Japan in the Yokosuka Strait, Malabar-12 in the Bay of Bengal, SIBMEX-12 with Singapore in the Andaman Sea and Bay of Bengal, KONKAN-12 with the UK, and INDRA-2012 with Russia. Simultaneously, China strictly abides by its "periphery" and "string of pearls" strategies taking every effort to prevent India from establishing naval supremacy and creating naval links with other Asian countries [10].

In 2001, the government of China began investing into the construction of a deepsea port situated on the Arabian Sea in Gwadar, Pakistan. With the help of this project, China is able to monitor the US maritime activity in the Persian Gulf, Indian activity in the Arabian Sea and the Indo-US naval collaboration in the Indian Ocean. Furthermore, as part of its "periphery strategy", China begins building genial relations with its immediate neighbour India, hoping to influence the spread of India's hegemony fuelled by its alliance with the USA. Despite former disagreements, Beijing does not want to jeopardize its relations with New Delhi. In June 2003, Prime Misnister 
Vajpayee paid a visit to China, in the course of which the countries agreed to build a strategic partnership for peace and prosperity and signed the Declaration on Principles for Relations and Comprehensive Cooperation [12].

In 2006, Chinese president Hu Jintao repaid a visit to New Delhi. Hu's agenda included developing a ten-point strategy to take the Sino-Indian relationship a step further. The key aspects of the joint declaration were:

- comprehensive development of the bilateral relations

- strengthening institute linkage and dialogue mechanism

- sustaining a lucrative commercial and economic exchange

- expanding mutual beneficial cooperation

- establishing mutual trust and confidence in the matters of security and defense

- securing trans-border connectivity

- mutual collaboration in the field of science and technology

- forming closer cultural ties and people-to-people communication

- cooperation on the regional and global stage

In Jun 2007, the two countries signed another agreement testifying to their "shared vision of $21^{\text {th }}$ century", resolving to promote the building of a harmonious world of durable peace and common prosperity through developing the Strategic and Cooperative Partnership for peace and prosperity between the two countries. In the agreement, India maintained very cordial policies on the issues that affect China's core interests, recognizing Taiwan province and Tibet autonomous region as part of China and pledging not to undertake any anti-China activities on their territories [2]. China, in its turn, mended its economic relations with New Delhi, making India its third largest trading partner. More than 150 Chinese enterprises and 60 companies are currently operating in India. In 2003, the two governments signed the Memorandum of Understanding (MOU) on the resumption of border trade through the Nathula Pass. The MOU sought to establish all-round economic cooperation, which heralded a new stage of business relations between the two countries. Following the agreement, there has been a rapid growth in bilateral trade in past few years. However, despite all mutually beneficial cooperation, neither state is ready to compromise their interests. Ever since the SinoIndian war of 1962, the Indian perception of China has been that of a major security threat. On the other hand, China realizes that India, backed by the US, is an endangerment to its economic interests in the IOR region [2].

Since 1960, China and Pakistan have been maintaining a close strategic relationship, which China has used as its main trump card to play against India and its growing power. Strategically, India is facing two immediate threats: Pakistan in the west and China in the north and northeast. According to Indian analysts, the solid Sino-Pak union allows Beijing to extend its influence to South Asia, balance out India in the military sphere and equipoise the Indo-US nexus [2]. Over the years, China has been a steady source of military equipment to Pakistan, and the countries have developed strong military ties. The most important shared interests between the two states are energy and security. Pakistan's convenient strategic location (it borders with South Asia, Central Asia, and West Asia) makes it an ideal gateway for cooperation in the three regions in the spheres of energy, trade and transportation. China with its booming economy needs a secure access to energy resources. There are multiple reasons behind 
the Chinese support of Pakistan: on the one hand, China intends to externally balance out India, both economically and politically, and thus prevent its further attempts to encircle China; on the other hand, Beijing needs a direct access to the Indian Ocean via the Arabian Sea and the Gwadar Port in order to monitor the actions of the Indo-US alliance in the IOR's SLOCs [7]. The construction of the China-Pakistan Economic Corridor (CPEC) in the context of the OBOR initiative, combined with the generous subsidiary which China allotted to help with the development of Pakistan's nuclear program and the completion of the Chashma Nuclear Power Complex (in the amount of \$207 million), has clearly served as a counter action for the US-Indian nuclear deal. The CPEC is a $\$ 52$ billion-worth mega project, conceived and designed by the Chinese government to support Pakistan in the energy sector, modernize its infrastructure and strengthen its economy by the construction of transportation networks, such as the Gwadar port [11].

\section{RECENT DEVELOPMENTS}

India's current Prime Minister Narendra Modi visited China with the purpose of "resetting ties" and decreasing tensions between the two Asian giants. The Chinese leader gave red carpet treatment to the Indian Prime Minister, and the two sides signed yet another MOU in a bid to promote all-round cooperation in various fields, including energy, education, and security. The two countries even referred to their newly re-established alliance as "Chindia" ("China" and "India" blending). So far, this informal summit has been China's most successful attempt to overcome the differences between two states and reach an important consensus [11]. In the context of China-Pakistan relations, the most significant latest development was the recent visit of Pakistan's Prime minister Imran Khan to China. In order to tackle Pakistan's fiscal crisis, the country's leader suggested all regional trade should be carried out in local currencies the Pakistani rupee (PKR) and Chinese yuan - rather than in US dollars, which will facilitate the development of the Sino-Pak trade relations.

\section{CHINA-RUSSIAN TIES: IMPLICATIONS OF THE INDO-US NEXUS}

In the light of the fact that Russia is a close ally of India and an ardent supporter of its nuclear energy policy, the Sino-Russian relations are quite complex in nature. During the President Bush era, relations between the US and Russia worsened due to Russia's full-fledged support of China in its opposition to US policies. Broadly speaking, whenever the interests of China and Russia concur, they "sing in unison", and when their interest diverge, they follow each their own path. The growing tension between Russia and the US is pushing Russia towards China, threatening America with such strong alliances as China-Russia and China-Russia-Pakistan [1].

The nexus between India and the US started a new chapter in global politics in general and Asian politics in particular. In his speech at the Bucharest NATO summit, former US president George Bush mentioned the intentions of NATO to "send its forces across the world for the future of freedom and peace of millions". That clearly signified that NATO had formed a new alliance and Russia and China are perceived as rivals. Moreover, the Bush administration announced its plan to replace Intercontinental 
Ballistic Missiles (ICBMs) with Anti-Ballistic Missiles (ABMs) on its military bases [6]. In 2008, at the Bastille summit, Russia and China conjointly condemned America's switch to ABMs.

On the bilateral level, China is improving its relations with Russia politically, economically and strategically. On July 22, 2008, the two countries signed an agreement that ended the long-running territorial dispute and finally determined the Russia-China borders. The demarcation of the border between the nations marked a new era in the SinoRussian relationships [1]. In 2001, China and Russia signed the Treaty of Good-Neighbourliness, Friendship and Cooperation", which included the decision about a joint action against Washington's attempts to extend its influence and establish world hegemony. In 2007, Russia and China took another step towards developing their economic relations. As Chinese Prime Minister Wen Jiabaa reported to the Russian media during his visit, China had set a target of a 12-billion-US dollar investment in the Russian economy by 2020 . He said that Chinese investors will sponsor a variety of projects in different areas, including mining, electricity, infrastructure, agriculture and manufacturing. With the improvement of China-Russia relations, both countries have expressed their interest in creating a "triangular" strategic partnership with India and Pakistan to counterpoise the US efforts to secure its influence in Asia [1].

China and Russia, however, had different reactions to the formation of the Indo-Us nexus. The two countries have different political, economic, and strategic approaches in their relations with India. Russia was India's close ally during the Cold War and provided extensive military support for the country after India established its independence. So, on one hand, there is the Russia-India nuclear alliance and, on the other hand, China is creating a nuclear nexus with Pakistan. After India teamed up with the US, its image on the international and regional arena has dramatically changed. The Indo-US influence in region creates anxiety in the anti-US faction and prevents China and Russia from dominating in the region.

The BRICS forum is an excellent platform for the participating countries to promote regionalism and economic development in the area. Among the primary objectives of the 2018 BRICS summit were promotion of worldwide peace, fight against gender discrimination, stimulation of economic growth and development of cooperation in the field of tourism. Shanghai Cooperation Organization (SCO) is another association which serves to enhance the regional cooperation among the Central Asian states, Russia and China, as well as to counter NATO's activities, specifically in the Central Asian Region.

\section{CONCLUSION}

Promoting the concept of a harmonious world and a multipolar global system, China employs rather amicable foreign policy in its periphery and especially in the South Asian region. Despite being one of the major global powers, China maintains friendly and cooperative relations with its immediate neighbors. Beijing openly professes nonbelligerent ideology, calling on other nations for peace, cooperation, common efforts towards economic progress, and regionalistic attitude to national problems. In the context of India-US relations, China strives to avoid any hegemony in South Asia and looks to create a triangular nexus India-US-China in order to avoid conflicts. Therefore, 
China's policies can be considered more mature, as the PRC has been able to maintain cordial relations with two South Asian nuclear states: Pakistan and India. The Asian regional powers, Russia, India, China and Pakistan, are working cooperatively to make the region more stable, integrated, economically robust and secure.

\title{
REFERENCES
}

[1] Bellacqua J. The Future of China-Russia Relations. Kentucky: University Press of Kentucky; 2010. $372 \mathrm{p}$.

[2] Bieri M. China in the Indian Ocean: Part of a Large Plan. ETH Zurich: Centre for Security Studies. 2014; 156.

[3] Cohen S.P. Emerging Power: India. Washington DC: Brookings Institution; 2002. 377 p.

[4] Deng Y., Wang F. China Rising: Power and Motivation in Chinese Foreign Policy. New York: Rowman \& Littelfield Publications; 2005. 349 p.

[5] Garver J.W. Protracted Contest: Sino-Indian Rivalry in the Twentieth Century. Seattle: University of Washington Press; 2002. 462 p.

[6] Ganguly S. India as an Emerging Power. London: Frank Cass; 2003. 233 p.

[7] Ghoshal B. China's Perception of India's 'Look East Policy' and Its Implications. New Delhi: Institute of Defence Studies and Analyses; 2013: 82-89.

[8] Hayes J. Constructing National Security: United States Relations with India and China. New York: Columbia University Press; 2013. 224 p.

[9] Talbott S. Engaging India: Diplomacy, Democracy and the Bomb. Washington: DC. Brookings Institution Press; 2004. 268 p.

[10] Tellis A., Mirski S. Crux of Asia: China, India and the Emerging Global Order. Washington, D.C: Carnegie Endowment publishers; 2013. 254 p.

[11] Waqas R.M. Nuclearization and Indian Ocean: Opportunities and Challanges. Journal of Pakistan and Gulf Studies. 2017. Available from: https://cpakgulf.org/2017/05/29/nuclearizationof-the-indian-ocean-opportunities-and-challenges/. Accessed: 22.02.2019.

[12] Wagner C. The Effects of China-Pakistan Economic Corridor. German Institute for International and Security Affairs. 2016. Available from: https://www.swp-berlin.org/fileadmin/contents/ products/comments/2016C25_wgn.pdf. Accessed: 22.02.2019.

[13] Yoshihava T. Chinese View of India in the Indian Ocean: A Geopolitical Perspective. Strategic Analysis. 2012; Vol. 36; 3: 489—500. DOI: 10.1080/09700161.2012.670446.

Научная статья

\section{КИТАЙСКОЕ ВОСПРИЯТИЕ ПАРТНЕРСТВА ИНДИИ И США: ПОСЛЕДСТВИЯ ДЛЯ КИТАЯ В РЕГИОНЕ ЮЖНОЙ АЗИИ (краткий обзор)}

\author{
Р.Д. Нисар \\ Классический университет Центрального Китая \\ № 152, Люою Роад, Ухань, Хубэй, КНР, 430079
}

\begin{abstract}
Аннотация. Автор отмечает, что после распада СССР США изменили приоритеты своей внешней политики и стали рассматривать экономический подъем Китая как угрозу интересам США. Из-за высоких темпов экономического роста и развития вооруженных сил Китайская Народная Республика стала конкурентом США на мировой арене. Автор приходит к выводу, что вследствие
\end{abstract}


этого США перестраивают свою политику в соответствии с геополитическими реалиями и рассматривают Индию в качестве мощного союзника для сдерживания Китая. Делается вывод о том, что в текущий период Индия и США переопределяют свои отношения и строят тесные связи для обеспечения общих интересов и противодействия возможным угрозам. Автор утверждает, что две главные стратегические цели Дели в целом совпадают с интересами США в Азии. Это, во-первых, предотвращение растущего влияния Китая в Азии и, во-вторых, развитие дружественных отношений с другими крупными азиатскими странами для региональной поддержки Индии. Основной геополитической задачей индо-американского партнерства в отношении Китая является окружение Китая в Азии. В контексте морской безопасности индо-американское сотрудничество в Индийском океане и военные учения в Малабаре определяются задачами контроля над китайскими военно-морскими и торговыми маршрутами и защитой морских путей. Автор приходит к выводу о том, что важной геополитической целью американского руководства является развитие альянса с Индией для сдерживания КНР.

Ключевые слова: индо-американские отношения, сдерживание, Индийский океан, морские пути сообщения, Китай и Южная Азия, китайско-российские отношения.

\section{Информация об авторе:}

Рана Даниш Нисар — аспирант Школы политики и международных исследований Классического университета Центрального Китая (KHP) (ORCID ID: 0000-0002-1354-5144) (e-mail: ranadanishnisar@gmail.com).

\section{Information about the author:}

Rana Danish Nisar — PhD Student of the School of Politics and International Studies, Central China Normal University (People's Republic of China) (ORCID ID: 0000-0002-1354-5144) (e-mail: ranadanishnisar@gmail.com).

Статья поступила в редакцию 08.03.2019.

Received 08.03.2019.

\section{Для цитирования:}

Nisar R.D. Chinese Perception of Indo-US Nexus: Implications for China in South Asian Region (Brief Overview) // Вестник Российского университета дружбы народов. Серия: Политология. 2019. T. 21. № 2. C. 311-322. DOI: 10.22363/2313-1438-2019-21-2-311-322.

\section{For citation:}

Nisar R.D. Chinese Perception of Indo-US Nexus: Implications for China in South Asian Region (Brief Overview). RUDN Journal of Political Science. 2019; 21(2): 311-322. DOI: 10.22363/2313-14382019-21-2-311-322. 